\title{
Erratum to: Chronic insulin therapy reduces adipose tissue macrophage content in LDL-receptor-deficient mice
}

\author{
J. Yoon · S. Subramanian $\cdot$ Y. Ding $\cdot$ S. Wang $\cdot$ \\ L. Goodspeed • B. Sullivan • J. Kim • K. D. O'Brien • \\ A. Chait
}

Published online: 21 April 2011

(C) Springer-Verlag 2011

\section{Erratum to: Diabetologia}

DOI 10.1007/s00125-011-2055-2

Unfortunately, the following acknowledgement was omitted from this paper:

This research was partially supported by research grant number 208-A-061-033 awarded by Yeungnam University in 2008 .

The online version of the original article can be found at http://dx.doi. org/10.1007/s00125-011-2055-2.

J. Yoon $\cdot$ S. Subramanian $\cdot$ Y. Ding $\cdot$ S. Wang $\cdot$ L. Goodspeed $\cdot$

A. Chait $(\bowtie)$

Diabetes Obesity Center for Excellence, Division of Metabolism,

Endocrinology and Nutrition, University of Washington,

815 Mercer Street, Box 358055, Seattle, WA 98109, USA

e-mail: achait@u.washington.edu

B. Sullivan · J. Kim $\cdot$ K. D. O'Brien

Division of Cardiology, University of Washington,

Seattle, WA, USA

Present Address:

J. Yoon

Yeungnam University College of Medicine,

Daegu, South Korea 